JAMP: Jurnal Adminitrasi dan Manajemen Pendidikan

Volume 1 Nomor 1 Maret 2018, Hal : 87-95

Tersedia Online di http://journal2.um.ac.id/index.php/jamp/

ISSN $x x x x-x x x x$ (online)

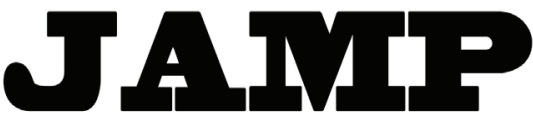

JURNAL ADMINISTRASI DAN MANAJEMEN PENDIDIKAN

\title{
KERJASAMA SMK DAN CISCO SYSTEM DALAM MENINGKATKAN MUTU PEMBELAJARAN TEKNIK KOMPUTER JARINGAN
}

\author{
Binti Zulfiana \\ Teguh Triwiyanto \\ R. Bambang Sumarsono \\ email: bintizulfiana_ap@yahoo.com \\ Universitas Negeri Malang, J1. Semarang No. 5 Malang 65145
}

\begin{abstract}
The poin of this research describes the management of cooperation, quality improvement indicators, and effort overcome constraint and support deceit cooperation between SMK Telkom Malang and Cisco System. The research used a qualitative approach with case study. he results of this study indicate that the cooperation SMK Telkom Malang with Cisco System in improving the quality of learning Computer Network Engineering includes planning, implementation, and evaluation. Indicators of improving the quality of learning is seen from the achievements of learners, both academic and non academic achievement. Furthermore, there are supporting and inhibiting factors, as well as efforts to overcome the barrier factor in SMK Telkom Malang cooperation with Cisco System.
\end{abstract}

Keywords: school cooperation, quality of learning

\begin{abstract}
Abstrak: Tujuan penelitian ini untuk mendeskripsikan tentang perencanaan, pelaksanaan, dan evaluasi kerjasama, indikator peningkatan mutu, serta factor pendukung dan penghambat kerjasama SMK Telkom Malang dengan Cisco System. Penelitian ini menggunakan pendekatan kualitatif dengan jenis penelitian studi kasus. Hasil penelitian ini menunjukkan bahwa kerjasama SMK Telkom Malang dengan Cisco System dalam meningkatkan mutu pembelajaran Teknik Komputer Jaringan meliputi perencanaan, pelaksanaan, dan evaluasi. Indikator peningkatan mutu pembelajaran tersebut dilihat dari prestasi peserta didik, baik prestasi akademik maupun non akademik. Selanjutnya terdapat faktor pendukung dan penghambat, serta upaya mengatasi faktor penghambat dalam kerjasama SMK Telkom Malang dengan Cisco System.
\end{abstract}

Kata kunci: kerjasama sekolah, mutu pembelajaran

Sekolah sebagai jalur pendidikan formal dituntut untuk mengembangkan potensi, kemampuan, dan bakat peserta didik. Hal ini ditujukan agar peserta didik yang telah menempuh pendidikan di jalur formal tersebut menjadi Sumber Daya Manusia (SDM) yang berkualitas. Peningkatan pendidikan yang bermutu tidak bisa hanya dilakukan oleh satu pihak saja, yaitu lembaga pendidikan, akan tetapi perlu adanya kerjasama antara sekolah dan berbagai pihak di masyarakat. Sekolah membutuhkan kerjasama dengan masyarakat dalam menjalankan programnya, agar keseluruhan program dapat terlaksana secara optimal. Salah satu strategi pembangunan pendidikan nasional dalam Undang-Undang Nomor 20 Tahun 2003 tentang Sistem Pendidikan Nasional adalah pemberdayaan peran serta masyarakat.

Kerjasama dengan masyarakat tidak hanya dalam bantuan berupa uang atau barang saja, akan tetapi juga dalam bentuk lain diantaranya pemikiran dan tenaga. Hal ini sesuai dengan pendapat Maisyaroh (2004:8) yang menyatakan peran serta masyarakat dapat berupa bantuan materiil dan nonmateriil. Bantuan materiil dapat berupa uang atau barang yang dapat memperlancar penyelenggaraan pendidikan. Bantuan non-materiil berupa tenaga dan pemikiran untuk kemajuan lembaga pendidikan. 
Kerjasama sekolah dengan masyarakat dalam penyelenggaraan pendidikan termasuk ke dalam kegiatan public relation (hubungan masyarakat). Maisyaroh (2004:3) mengelompokkan masyarakat secara umum menjadi tiga, yaitu masyarakat orangtua, masyarakat yang terorganisasi, dan masyarakat luas. Masyarakat orangtua adalah orangtua dari peserta didik yang sedang menempuh pendidikan. Masyarakat yang terorganisasi adalah masyarakat yang tergabung dalam sebuah kelompok atau organisasi tertentu, diantaranya perusahaan, Dewan Perwakilan Rakyat (DPR), rumah sakit, puskesmas, dan Lembaga Swadaya Masyarakat (LSM). Sedangkan masyarakat luas adalah masyarakat yang terdiri dari individuindividu atau pribadi-pribadi yang tidak terkait secara langsung terhadap penyelenggaraan pendidikan.

Salah satu kelompok masyarakat adalah perusahaan dan salah satu teknik kontribusi masyarakat adalah pemberian kesempatan kepada masyarakat untuk terlibat dalam penyelenggaraan pendidikan. Sekolah Menengah Kejuruan (SMK) Telkom Malang menjalin kerjasama dengan perusahaan terkemuka di dunia yang memproduksi perangkat keras untuk jaringan internet dan intranet, yaitu Cisco System. Kerjasama tersebut berlaku untuk program keahlian Teknik Komputer Jaringan (TKJ), yang merupakan salah satu program keahlian di SMK Telkom Malang. Hal ini karena Cisco System merupakan perusahaan yang bergerak di bidang networking yang sesuai dengan program keahlian TKJ.

Lembaga pendidikan atau sekolah dapat bekerjasama dengan Cisco System karena Cisco System tidak hanya membuat jaringan komputer saja. Akan tetapi juga menyediakan program pendidikan yang disebut Cisco Networking Academy (CNA). Menurut Sofana (2012:44) tujuan CNA tersebut adalah untuk menghasilkan tenaga profesional yang memahami jaringan komputer secara teori maupun praktik. Sebagai bukti peserta akademi telah menyelesaikan program studi dengan baik maka Cisco System memberikan sertifikat bagi peserta yang lulus tes. Sertifikat Cisco System merupakan sertifikasi internasional yang diakui di dunia. Hal ini menyebabkan lembaga pendidikan banyak yang tertarik kepada sertifikasi Cisco System, sehingga memasukkan Cisco Certified Network Associate (CCNA) pada kurikulum pendidikan.

Setiap tahun ada ratusan ribu siswa Cisco Networking Academy di seluruh dunia mendapatkan keterampilan yang dibutuhkan untuk membangun, mendesain, dan memelihara jaringan komputer, meningkatkan prospek karir mereka untuk memenuhi kebutuhan di era global sebagai profesional. Dengan 10.000 akademi di 165 negara, Cisco Networking Academy membantu individu mempersiapkan sertifikasi yang diakui industri dan informasi entry-level dan teknologi komunikasi karir di hampir setiap jenis industri. Siswa mengembangkan keterampilan dasar TIK sementara memperoleh keterampilan karir abad ke-21 penting dalam pemecahan masalah, kolaborasi, dan berpikir kritis.

Cisco System merupakan perusahaan yang berada di Amerika, terkait programnya CNAP di setiap negara terdapat unit yang disebut Instructor Training Center (ITC) dan Academy Support Center (ASC), di Indonesia berada di Universitas Gajah Mada (UGM). Kerjasama dengan Cisco System tersebut tak terkecuali juga menarik perhatian SMK Telkom Malang. Kerjasama antara sekolah kejuruan dengan perusahaan merupakan hal umum yang sering terjadi. Namun, biasanya kerjasama sekolah kejuruan dengan perusahaan dalam bentuk kegiatan praktek kerja industri atau perekrutan tenaga kerja. SMK Telkom Malang memiliki bentuk kerjasama atau kontribusi dari perusahaan dalam bentuk lain. Perusahaan Cisco System memberikan andil dalam proses pembelajaran berupa kurikulum online, alat belajar virtual, dukungan intruksional, pelatihan guru, dan kesempatan pengembangan professional bagi instruktur guna meningkatkan mutu pembelajaran Teknologi Komputer Jaringan di SMK Telkom Malang. Selain itu, pemberian sertifikat yang diakui secara global bagi peserta didik yang lulus ujian merupakan bentuk penghargaan dari Cisco System yang kelak dapat digunakan dalam dunia kerja.

\section{METODE}

Pendekatan yang digunakan dalam penelitian ini yaitu pendekatan kualitatif. Wiyono (2007:71) menyatakan pendekatan kualitatif merupakan penelitian yang dilakukan secara intensif dan sistematis untuk memperoleh informasi. Peneliti menggunakan pendekatan kualitatif untuk mendeskripsikan kerjasama SMK Telkom Malang dengan Cisco System dalam meningkatkan mutu pembelajaran TKJ dalam bentuk kata-kata tertulis. Penelitian yang mendalam dan menyeluruh akan mendapatkan data 
yang dapat dipertanggungjawabkan. Peneliti mendeskripsikan secara rinci dan sistematis terkait fokus penelitian. Oleh karena itu, jenis penelitian ini adalah studi kasus. Wiyono (2007:77) menyatakan studi kasus merupakan kegiatan penyelidikan untuk mendeskripsikan dan menganalisis secara intensif dan terperinci suatu gejala atau unit sosial tertentu, seperti individu, kelompok, komunitas, atau lembaga.

Kehadiran peneliti dalam penelitian merupakan bagian yang penting, hal ini agar peneliti mengetahui kondisi lokasi penelitian secara menyeluruh dan mendalam. Kehadiran peneliti tidak dapat diwakilkan kepada orang lain dan sangatlah penting. Hal ini karena peneliti merupakan instrumen kunci atau instrumen utama dalam penelitian kualitatif (Sugiyono, 2009:223). Peneliti menjadi satusatunya pengumpul data dalam penelitian. Peneliti mengikuti kelas Cisco Academy untuk melihat secara langsung situasi pembelajaran. Kehadiran peneliti juga untuk melihat secara langsung sarana dan prasarana serta media dalam pembelajaran kelas Cisco Academy. Selain itu, dengan adanya kehadiran peneliti di lapangan akan menjalin keakraban dengan narasumber, keakraban akan mendukung dalam menggali lebih dalam dan mendapatkan data atau informasi yang dibutuhkan. Setelah mendapatkan data atau informasi yang dibutuhkan peneliti akan mampu memahami kondisi di lapangan, sehingga data dan informasi yang peneliti tuangkan dalam hasil penelitian benar-benar terjamin validitas isinya.

Penelitian ini dilakukan di SMK Telkom Malang yang beralamat di Jalan Danau Ranau Sawojajar, Kecamatan Kedungkandang, Kota Malang. Sekolah tersebut teletak di kawasan Perumahan Sawojajar. Alasan peneliti memilih lokasi ini karena di SMK tersebut menjalin kerjasama dengan perusahaan, yakni Cisco System. Selain itu, SMK Telkom Malang merupakan SMK di Malang yang pertama kali menjalin kerjasama dengan Cisco System. Peneliti menggunakan teknik snowball sampling, Alfianika (2016:108) menyatakan snowball sampling adalah teknik penentuan sampel yang mula-mula jumlahnya kecil, kemudian membesar seperti bola salju yang menggelinding yang lama-lama menjadi besar.

Peneliti menggunakan observasi untuk melengkapi informasi dan hasil wawancara. Observasi digunakan peneliti karena dalam wawancara memiliki keterbatasan, diantaranya informasi yang diperoleh belum menggambarkan situasi yang alami. Ada beberapa tingkat observasi yang dilakukan dalam penelitian kualitatif. Wiyono (2007:78) mengungkapkan beberapa macam observasi dalam penelitian kualitatif, diantaranya observasi partisipasi nihil, observasi pasrtisipasi sedang, observasi partisipasi aktif, dan observasi partisipasi penuh. Observasi yang dilakukan peneliti adalah observasi partisipasi nihil. Hal ini karena peneliti hanya mengamati kegiatan yang dilakukan kelompok sasaran penelitian. Peneliti mengamati proses pembelajaran yang menerapkan di kelas Cisco Academy.

Wawancara adalah percakapan yang dilakukan antara peneliti dan informan. Wiyono (2007:79) menyatakan tujuan wawancara untuk memperoleh informasi yang lebih dalam, mengkonstruksi, dan memproyeksikan mengenai orang, kejadian, kegiatan, organisasi, perasaan, motivasi, tuntutan, kepedulian, dan lain-lain. Proses dalam wawancara dilakukan secara langsung oleh peneliti dengan bertatap muka langsung (face to face) dengan informan. Wawancara kepada satu informan tidak hanya dilakukan sekali, namun berkali-kali sesuai dengan kebutuhan penelitian. Hal ini menunjukan peneliti melakukan wawancara mendalam. Sutopo (2006:72) menyatakan wawancara mendalam adalah proses memperoleh informasi melalui tanya jawab dengan bertatap muka antara peneliti dengan informan, dengan atau tanpa menggunakan pedoman wawancara dimana peneliti dan informan terlibat dalam kehidupan sosial yang relatif lama.

Dokumentasi adalah teknik pengumpulan data dengan cara menganalisis dokumen atau data yang sudah ada di lapangan. Terdapat beberapa jenis macam dokumen, Wiyono (2007:81) menyatakan macam-macam dokumen diantaranya dokumen pribadi, dokumen resmi, foto, ataupun bahan statistik. Dokumentasi yang digunakan peneliti adalah mengumpulkan data yang tertulis berupa dokumen sekolah serta foto. Selain itu juga berupa sertifikat Cisco System yang telah diperoleh peserta didik.

Analisis data dalam penelitian kualitatif dilakukan selama dan sesudah pengumpulan data di lapangan. Analisis dilakukan dengan membandingkan antara data yang diperoleh dari berbagai sumber (sumber primer dan sekunder) serta berbagai teknik (wawancara, obeservasi, dan dokumentasi). Analisis data dilakukan dengan reduksi data, display data, dan verifikasi data. Hasil analisis data selanjutnya di cek keabsahannya melalui triangulasi, pengecekan anggota, kecukupan bahan referensial, dan perpanjangan 
keikutsertaan. Proses pengumpulan data dalam penelitian ini melalui beberapa tahapan, yaitu: tahap persiapan, tahap pelaksanaan, dan tahap pelaporan.

\section{HASIL}

Kerjasama SMK Telkom Malang dengan Cisco System dilakukan sejak tahun 2005. Perlu adanya perencanaan yang matang untuk menjalin kerjasama tersebut. Oleh karena itu, perencanaan kerjasama melalu serangkaian tahap-tahap. Tahap pertama adalah menentukan tujuan yang jelas, tujuan SMK Telkom Malang bekerjasama dengan Cisco System untuk meningkatkan mutu pembelajaran khususnya untuk TKJ. Tahap kedua adalah mengumpulkan informasi, informasi yang dikumpulkan akan digunakan untuk menyusun perencanaan. Informasi yang dikumpulkan diantaranya informasi mengenai CNAP, persyaratan kerjasama/persyaratan menjadi Cisco Academy, dan biaya yang diperlukan. Tahap ketiga adalah tahap menyusun perencanaan, perencanaan disusun berdasarkan informasi yang dikumpulkan. Tahap terakhir menetapkan rencana, rencana yang ditetapkan harus menjawab $5 \mathrm{~W}$ dan $1 \mathrm{H}$ (what, who, where, why, when, dan how).

Pelaksanaan kerjasama SMK Telkom Malang berdasarkan perencanaan yang telah ditetapkan. Tahapan pelaksanaan kerjasama dengan Cisco System memiliki dua tahapan utama yaitu memenuhi persyaratan menjadi Cisco Academy dan membuka kelas. Tahap pertama dalam pelaksanaan kerjasama SMK Telkom Malang dengan Cisco System adalah memenuhi persyaratan kerjasama/menjadi Cisco Academy. Pada tahap ini persyaratan pertama adalah institusi pendidikan resmi, mengirimkan surat permohonan kepada Cisco System melalui e-mail. Persetujuan dari Cisco System berupa e-mail aktivasi akun institusi. Tahap selanjutnya menunggu jadwal pelatihan instruktur. Calon instruktur menjalani pelatihan di ITB yang dulu merupakan Local Academy, saat ini ditangani oleh Instructor Training Center di UGM. Setelah mengikuti pelatihan instruktur, calon instruktur menjalani ujian. Setelah calon instruktur dinyatakan lulus, tahap selanjutnya yaitu membuka kelas Cisco Academy. Langkah pertama setelah dapat membuka kelas adalah melengkapi sarana dan prasarana sesuai dengan standar dari Cisco System. Selanjutnya menentukan individu yang berperan sebagai instruktur, netacad success lead, dan netacad contact. Selanjutnya menerapkan CNAP. Penerapan CNAP menggunakan pembelajaran berbasis internet, peserta didik dan instruktur memiliki akun di www.netacad.com. Web tersebut berisi fungsi teach, manage, dan learn untuk akun instruktur, sedangkan untuk peserta didik terdapat fungsi learn.

Kegiatan evaluasi diperlukan untuk mengetahu kekurangan dalam pelaksanaan kerjasama SMK Telkom Malang dengan Cisco System. Kegiatan evaluasi melibatkan kedua belah pihak, baik dari pihak sekolah maupun pihak Cisco System. Pihak sekolah yang terlibat dalam evaluasi diantaranya kepala sekolah, wakil kepala sekolah, dan guru. Kemudian Cisco System terlibat dalam evaluasi pembelajaran menggunakan penilaian online. Hal-hal yang di evaluasi selain evaluasi pembelajaran penerapan CNAP, sumber daya manusia, dan sarana prasarana.

Indikator peningkatan mutu pembelajaran TKJ hasil kerjasama dengan Cisco System adalah prestasi peserta didik dan kesiapan peserta didik dalam dunia kerja. Prestasi-prestasi diraih oleh peserta didik baik prestasi akademik dan non akademik. Kesiapan di dunia keja dengan memperoleh sertifikat Cisco yang diakui secara internasional, yang dapat digunakan untuk melamar pekerjaan.

Faktor pendukung kerjasama SMK Telkom Malang dengan Cisco System terdiri dari faktor internal dan faktor eksternal. Faktor internal diantaranya dana, sarana dan prasarana, serta SDM telah siap. Selanjutnya faktor eksternalnya adalah persetujuan kerjasama dari pihak Cisco System.

Faktor penghambat kerjasama SMK Telkom Malang dengan Cisco System diantaranya kendala teknis, yaitu terkadang koneksi internet buruk. Upaya untuk mengatasi penghambat tersebut sekolah mengupayakan memberikan fasilitas wifi khusus kelas Cisco Academy agar pembelajaran berjalan lancar. Selain itu, jumlah tenaga yang berperan dalam Cisco Academy masih kurang. 


\section{PEMBAHASAN}

Perencanaan merupakan tahapan pertama manajemen. Perencanaan sebagai dasar dalam melaksanakan kegiatan. Berdasarkan hasil temuan peneliti di SMK Telkom Malang, langkah pertama dalam menyusun perencanaan adalah menentukan terlebih dahulu tujuan kerjasama, setelah itu mengumpulkan informasi yang akan digunakan untuk menyusun perencanaan, selanjutnya menyusun perencanaan, dan tahap terakhir adalah menetapkan perencanaan. Hal tersebut sesuai dengan pendapat Setiono. Setiono (dalam Torang, 2013:168) menjelaskan ada tujuh tahapan, diantaranya "(1) membuat perkiraan yang dihubungkan dengan pencapaian tujuan, (2) menetapkan tujuan, (3) mengumpulkan data-data informasi yang diperlukan sebagai bahan penyusunan perencanaan, (4) menentukan alternatif, (5) menyusun rencana, (6) menetapkan rencana, dan (7) melaksanakan rencana".

Tahap kedua dalam perencanaan adalah mengumpulkan informasi secara lengkap. Informasi yang dikumpulkan antara lain mengenai Cisco System, khususnya mengenai programnya yaitu CNAP. Persyaratan dan budget yang diperlukan untuk bekerjasama dengan Cisco System atau menjadi Cisco Academy. Hal ini menunjukkan di dalam perencanaan kerjasama tersebut memuat fungsi penganggaran (budgeting). Hal ini sesuai dengan pendapat Amsyah (2003:6) "perencanaan (planning) yang terdiri dari fungsi-fungsi perencanaan dan penganggaran (budgeting)". Jadi, secara operasional terdapat kelompokkelompok fungsi manajemen, fungsi penganggaran (budgeting) merupakan salah satu bagian dari fungsi perencanaan.

Penetapan perencanaan kerjasama yang dihasilkan harus dapat menjawab $5 \mathrm{~W}+1 \mathrm{H}$. Yang pertama, what, apa yang akan dilaksanakan. Yang kedua who, yaitu siapa yang akan melaksanakan. Yang ke tiga where, dimana pelaksanaannya. Yang ke empat why, mengapa melaksanakannya. Yang ke lima when, kapan dilaksanakan. Dan yang terakhir adalah how, bagaimana pelaksanaannya. Hal ini sesuai dengan pendapat Widjaya (dalam Torang, 2013:167), perencanaan adalah langkah-langkah "apa" (terkait dengan penentuan tujuan) yang akan dilaksanakan, "mengapa" (berkaitan dengan alasan atau motif perlunya kegiatan itu), "bagaimana" (terkait dengan prosedur kerja sasaran dan biaya) melakukannya, "bilamana" (terkait dengan pelaksanaan kegiatan; penahapan kegiatan sampai dengan selesai), "siapa" (terkait dengan orang-orang yang turut terlibat dalam pelaksanaan kegiatan), "penilaian" (berkaitan dengan kegiatan yang sedang dan telah selesai dilakukan), dan "faktor pendukung dan penghambat" (terkait dengan faktor-faktor yang dapat mempengaruhi pelaksanaan dan kegiatan) untuk maksud penyesuaian dan perubahan rencana yang akan melakukannya agar tujuan dapat tercapai seefektif dan efisien mungkin.

Berdasarkan paparan di atas dapat disimpulkan, bahwa perencanaan merupakan kegiatan awal yang dilaksanakan sebagai dasar pelaksanaan. Di dalam perencanaan memuat dua fungsi yaitu fungsi perencanaan dan fungsi penganggaran (budgeting). Kegiatan perencanaan memiliki tahap-tahap, tahap pertama menentukan tujuan yang jelas terlebih dahulu, tahap kedua mengumpulkan informasi yang akan digunakan untuk menyusun rencana, ke tiga menentukan alternatif, tahap ke empat menyusun rencana, dan tahap terakhir adalah menetapkan rencana. Penetapan rencana harus dapat menjawab apa, mengapa, bagaimana, siapa, dan apa saja faktor pendukung dan penghambat. Hal ini agar perencanaan dapat berjalan secara efektif dan efisien.

Perencanaan merupakan bentuk realisasi dari perencanaan yang telah disusun sebelumnya. Pelaksanaan terdiri dari fungsi pengarahan, penggiatan, pengorganisasian, dan penggiatan. Amsyah (2003:6) menyatakan “... pelaksanaan (operating) yang terdiri dari fungsi-fungsi pengarahan (directing), penggiatan (actuating), pengorganisasin (organizing), dan koordinasi (coordinating) ...”.

Pelaksanaan kerjasama dimulai dengan memenuhi persyaratan menjadi Cisco Academy, mulai dari mengirimkan surat permohonan, mendapat persetujuan lalu salah satu guru menjalani pelatihan instruktur, setelah guru yang mengikuti pelatihan lulus baru bisa diadakan kerjasama menjadi Cisco Academy. Hal ini menunjukkan sekolah yang aktif dalam kegiatan hubungan masyarakat tersebut. Hal ini sesuai dengan pendapat Maisyaroh (2004:19) yang menyatakan "pelaksanaan kerjasama menuntut pihak sekolah lebih proaktif dalam menjalin kerjasama sehingga kelompok terorganisasi yang ada mau dan berpartisipasi aktif dalam meningkatkan kualitas lembaga pendidikan”. 
Tahap selanjutnya dalam pelaksanaan kerjasama adalah melengkapi sarana dan prasarana. Hal ini bertujuan untuk menghindari terbengkalainya sarana dan prasarana apabila guru yang mengikuti pelatihan tidak langsung lulus.

Selanjutnya menentukan individu yang berperan sebagai instruktur, netacad succes lead, dan netacad contact. Tahap ini sekolah telah menjalankan fungsi pengorganisasian, akan tetapi sayangnya semua bagian tersebut pada akhirnya diperankan oleh satu orang, yaitu guru yang menjalani pelatihan sebagai calon instruktur. Jadi, beliau merangkap tiga pekerjaan sekaligus. Padahal di dalam suatu kegiatan manajemen hendaknya melibatkan beberapa orang untuk melakukan pekerjaan tertentu sehingga dapat berjalan efektif, efisien, dan tujuan dapat tercapai.

Tahap selanjutnya adalah menerapkan CNAP, penerapan CNAP diantaranya kurikulum online dan teknologi yang digunakan. Penerapan CNAP ini diharapkan dapat meningkatkan mutu pembelajatran. Gasperz (dalam Zazin, 2011:54) yang menyatakan mutu memiliki devinisi yang berbeda dan bervariasi, dari yang konvensional hingga modern. Definisi konvensional mendefinisikan karakteristik suatu produk, sedangkan definisi modern mendefinisikan bahwa mutu merupakan suatu produk/hasil baik berupa barang ataupun jasa yang mampu memenuhi kebutuhan pelanggan. Jadi, mutu dapat diperbaiki karena pada dasarnya tidak ada proses yang sempurna.

Berdasarkan pendapat Gasperz tersebut, menunjukkan bahwa mutu dalam definisi modern merupakan suatu hasil salah satunya jasa yang mampu memenuhi kebutuhan pelanggan. Kurikulum yang digunakan dan teknologi yang digunakan seperti Cisco Packet Tracer, Cisco Aspire, penilaian online, dan juga social media tools, serta yang tidak kalah penting adalah sertifikat Cisco yang diakui secara internasional, merupakan suatu jasa yang dirasa mampu memenuhi kebutuhan peserta didik. Hal tersebut menjadikan kerjasama antara SMK Telkom Malang dan Cisco System menjanjikan mutu pembelajaran khususnya untuk program keahlian TKJ dapat meningkat.

Evaluasi kerjasama di SMK Telkom Malang dilaksanakan oleh kepala sekolah, wakil kepala sekolah, dan guru. Selain itu Cisco System juga terlibat di dalam evaluasi. Cisco System terlibat dalam evaluasi pembelajaran. Evaluasi dilakukan setiap semester agar apabila terjadi kesalahan bisa segera dilakukan, hal ini sesuai dengan karakteristik pengendalian. Terry (2009:170) menyebutkan karakteristik pengendalian, yaitu: "(1) jenis pengendalian yang digunakan harus sesuai dengan kegiatan yang bersangkutan; dan (2) penyimpangan yang perlu dikoreksi harus segera dilakukan identifikasi".

Pendapat Terry tersebut menunjukan pengendalian harus sesuai dengan kegiatan yang bersangkutan dan kesalahan segera dikoreksi untuk dilakukan perbaikan. Hal-hal yang dievaluasi dalam kerjasama SMK Telkom Malang dengan Cisco System diantaranya evaluasi pembelajaran, penerapan CNAP, sumber daya manusia, serta sarana dan prasarana. Evaluasi pembelajaran melalui penilaian online yang melibatkan Cisco System. Penerapan CNAP meliputi kurikulum online dan teknologi yang digunakan. Sumber daya manusia terkait peranan yang terlibat langsung dalam kelas Cisco Academy meliputi netacad success lead, netacad instructur, dan netacad contact. Sarana dan prasarana meliputi ruang kelas dan sarana yang mendukung seperti LCD, wifi, dan fasilitas pendukung lainnya.

Evaluasi kerjasama tersebut bertujuan untuk memperbaiki kegiatan-kegiatan yang telah dilaksanakan sehingga mendapatkan hasil sesuai yang direncanakan. Hal ini sesuai dengan pendapat Suparmoko (2007:71), fungsi pengawasan diterapkan oleh seorang manajer dengan melakukan penilaian dan mengendalikan jalannya kegiatan organisasi. Fungsi pengawasan bertujuan meluruskan kembali kesalahan dan penyimpangan yang terjadi agar sesuai dengan rencana dan tujuan organisasi. Proses pengawasan dilakukan dengan penetapan standar dan cara kerja, pengukuran prestasi kerja, memberikan pengarahan, dan melakukan tindakan perbaikan.

Indikator peningkatan mutu pembelajaran TKJ hasil kerjasama dengan Cisco System yaitu prestasidan kesiapan peserta didik di dunia kerja. Hal ini sesuai dengan pendapat Menurut Ali (2009:251) "indikator peningkatan kualitas pendidikan diukur dari pencapaian kecakapan akademik dan non-akademik yang memungkinkan lulusan dapat beradaptasi terhadap perubahan masyarakat dalam berbagai bidang baik di tingkat lokal, nasional maupun global". Prestasi-prestasi akademik dan non akademik dari berbabagi perlombaan di tingkat kota, provinsi, nasional bahkan asia pasific telah diraih oleh peserta didik SMK 
Telkom Malang. Selain itu kesiapan peserta didik di dunia kerja dengan berbekal sertifikat yang diakui secara internasional menjadikan lulusan SMK Telkom mempunyai nilai plus dalam persaingan di era global ini.

Keberhasilan kerjasama SMK Telkom Malang dengan Cisco System tidak lepas dari adanya faktor pendukung. Hal ini sesuai dengan pendapat Nurkolis (2006:130) menyatakan"suatu program yang dirancang tidak akan berjalan dan berhasil secara optimal apabila tidak tersedia berbagai faktor pendukung". Faktor pendukung dalam kerjasama tersebut terdiri dari faktor eksternal dan internal. Faktor internal diantaranya kesiapan calon instruktur dan kesiapan sekolah. Kesiapan calon instruktur yaitu kesiapan guru yang ditunjuk mengikuti pelatihan. Sedangkan kesiapan sekolah yaitu kesiapan sekolah dalam menyediakan sarana dan prasarana, serta dana.

Saat kerjasama SMK Telkom Malang berlangsung ada beberapa faktor penghambat. Faktor penghambat dalam kerjasama tersebut hanya terdiri dari faktor internal saja. Faktor internal penghambat kerjasama tersebut diantaranya kurangnya SDM dan kurang maksimalnya sarana penunjang yaitu internet. Kurangnya SDM menjadi penghambat karena saat ini instruktur hanya ada satu, sedangkan satu kelas Cisco dianjurkan berisi 12 peserta didik agar pembelajaran berjalan optimal.

Selanjutnya kurang maksimalnya sarana penunjang yaitu internet, pada saat berjalannya pembelajaran koneksi internet tiba-tiba lemah. Kurang maksimalnya sarana tersebut sesuai dengan pendapat Suparmoko (2007:71) yang menyatakan, fungsi-fungsi manajemen tidaklah mudah untuk diterapkan karena terdapat beberapa hambatan. Hambatan dalam fungsi manajemen dibagi menjadi dua, yaitu hambatan internal dan hambatan eksternal. (1) hambatan internal, (a) manajer tidak memahami dengan baik beberapa aspek yang harus diperhatikan berkaitan dengan penerapan fungsi manajemen pada suatu organisasi/perusahaan, (b) kurangnya komunikasi antara satu bagian dengan bagian lain yang terintegrasi dalam organisasi sehingga tidak tercipta kesalahpahaman visi dan misi perusahaan, (c) para pegawai atau bawahan atau anggota organisasi belum siap benar untuk melaksanakan fungsifungsi manajemen yang telah disusun oleh manajer, (d) adanya ketidakpastian dalam pelaksanaan fungsi manajemen disertai dengan sarana dan prasarana organisasi yang belum mendukung; (2) hambatan eksternal, (a) berbagai peraturan perundang-undangan dan kebijakan pemerintah yang bertentangan dengan fungsi manajemen yang diterapkan dalam organisasi, (b) pengaruh persepsi (image) negatif dari masyarakat luar berkaitan dengan keberadaan organisasi, (c) faktor iklim dan cuaca yang tidak mendukung.

Berdasarkan pendapat Suparmoko tersebut, salah satu hambatan internal sarana dan prasarana yang belum mendukung. Kemudian jika ditinjau dari hambatan eksternal pada pendapat Supratmoko tersebut, SMK Telkom Malang memang tidak menghadapi hambatan tersebut. Untuk mengatasi faktor penghambat kerjasama, sekolah sedang mengupayakan penambahan instruktur dan memberikan fasilitas wifi khusus kelas Cisco Academy agar pembelajaran berjalan lancar.

\section{KESIMPULAN DAN SARAN}

\section{Kesimpulan}

Tahap perencanaan kerjasama sekolah dengan Cisco System, pertama menentukan tujuan yang jelas terlebih dahulu. Tujuan SMK Telkom Malang yakni meningkatkan mutu pembelajaran program keahlian TKJ. Berdasarkan tujuan tersebut Cisco System, memiliki progam yang bernama CNAP yang dirasa sekolah mampu meningkatkan mutu pembelajaran TKJ.

Tahap kedua, mengumpulkan informasi. Informasi yang dikumpulkan diantaranya informnasi mengenai CNAP, persyaratan kerjasama untuk menjadi Cisco Academy, dan biaya yang diperlukan. Tahap ketiga, menyusun perencanaan. Setelah informasi terkumpul, informasi tersebut digunakan untuk menyusun rencana.

Tahap terakhir, menetapkan perencanaan. Penetapan perencanaan kerjasama SMK Telkom Malang dengan Cisco System, hasilnya harus menjawab 5W dan 1 H. Pertama, what, yaitu kerjasama sekolah dnegan Cisco System. Kedua, who, yang ditugaskan Bapak Anton. Ketiga, where, pelatihan di ITC 
terletak di UGM. Keempat, why? Karena Cisco System mempunyai program yang disebut CNAP yang diharapkan mampu untuk meningkatkan mutu pembelajaran TKJ Ke lima, when, tahun 2005. Ke enam, how, dengan mengajukan surat permohonan menjadi Cisco Academy, setelah di setujui guru SMK Telkom mengikuti pelatihan di ITC, setelah guru lulus menjadi instruktur membuka kelas.

Pelaksanaan kerjasama SMK Telkom Malang dengan Cisco System merupakan upaya sekolah mewujudkan perencanaan yang telah disusun, kegiatannya meliputi: pertama, memenuhi persyaratan menjadi Cisco Academy. Kedua, membuka kelas Cisco Academy. Persyaratan yang dipenuhi untuk menjadi Cisco Academy, pertama merupakan institusi pendidikan resmi, dalam hal ini tentu saja SMK Telkom Malang lolos. Persyaratan kedua, mengirimkan surat permohonan kerjasama menjadi Cisco Academy melalui email. Setelah mengirimkan email, SMK Telkom Malang langsung mendapat persetujuan berupa balasan email yang di dalamnya terdapat aktivasi akun institusi. Selanjutnya sekolah menunggu jadwal pelatihan yang diadakan di ITC. Kemudian, guru yang ditunjuk mengikuti pelatihan calon instruktur Cisco Academy. Selanjutnya, calon instruktur menjalani ujian dan dinyatakan lulus menjadi instruktur. Langkah selanjutnya yaitu membuka kelas.

Ada beberapa proses yang dilakukan sekolah dalam membuka kelas Cisco Academy. Pertama, melengkapi sarana dan prasarana yang sesuai dengan standar yang ditentukan Cisco System. Selanjutnya, menentukan individu yang berperan sebagai instruktur, netacad success lead, dan netacad contact. Kemudian selanjutnya, menerapkan CNAP.

Proses evaluasi kerjasama SMK Telkom Malang dengan Cisco System meliputi . Pertama, melibatkan kepala sekolah, waka humas, dan pendidik setiap akhir tahun pelajaran. Kedua, evaluasi pembelajaran setiap akhir semester. Ketiga, evaluasi yang melibatkan Cisco System bagi peserta didik yang menginginkan sertifikat berkelas internasional, yaitu sertifikat CCNA. Keempat, hal-hal yang di evaluasi yaitu penerapan CNAP, sumber daya manusia, serta sarana dan prasarana.

Indikator peningkatan mutu pembelajaran TKJ hasil kerjasama dengan Cisco System adalah prestasi peserta didik dan kesiapan peserta didik menghapi dunia kerja. Prestasi yang diraih peserta didik SMK Telkom Malang berupa prestasi akademik dan non akademik. Prestasi yang diraih peserta didik dapat menarik calon peserta didik baru di SMK Telkom Malang. Terkait kesiapan peserta didik menghadapi dunia kerja, sertifikat yang diberikan Cisco System merupakan sertifikat yang diakui secara internasional. Sertifikat tersebut dapat digunakan untuk melamar kerja dan menjadi nilai lebih sehingga banyak peserta didik yang sudah diterima kerja bahkan saat belum lulus sekolah.

Keberhasilan kerjasama SMK Telkom Malang dengan Cisco System tidak lepas dari adanya faktor pendukung. Faktor pendukung kerjasama ini terdiri dari faktor internal dan faktor eksternal. Faktor internal yang mendukung kerjasama ini diantaranya kesiapan sekolah dalam hal dana maupun sarana dan prasarana, serta kesiapan guru yang ditunjuk menjalani pelatihan calon instruktur. Guru yang menjalani pelatihan calon instruktur berperan sangat penting dalam kerjasama tersebut. Hal ini karena, jika calon instruktur tidak lulus menjadi instruktur maka kelas Cisco Academy tidak dapat dibuka. Sedangkan, faktor eksternal dalam kerjasama ini yaitu persetujuan kerjasama menjadi Cisco Academy dari Cisco System. Tanpa adanya persetujuan dari Cisco System, sekolah tidak dapat mengirimkan guru untuk menjalani pelatihan calon instruktur, sehingga tentu saja tidak dapat membuka kelas Cisco Academy.

Faktor penghambat kerjasama SMK Telkom Malang dengan Cisco System hanya terdiri dari faktor internal saja. Faktor pennghambat tersebut diantaranya kurangnya SDM dan kurang maksimalnya sarana penunjang yaitu internet.

Pihak sekolah terus melakukan evaluasi setiap tahunnya, hingga sekarang hanya tersisa dua hambatan. Pihak sekolah merencanakan untuk menambah SDM, namun tentunya dengan perencanaan dan pertimbangan yang matang. Hal-hal yang di pertimbangkan untuk menambah SDM diantaranya dana dan kesiapan guru yang akan mengikuti pelatihan. Hal ini dimaksudkan agar langkah yang dilakukan sekolah dapat berjalan secara efektif dan efisien. Selanjutnya untuk sarana pendukung seperti internet, sekolah berencana memberikat wifi khusus untuk kelas Cisco Academy agar pembelajaran dengan program e-learning tersebut dapat berjalan lancar. 


\section{Saran}

Berdasarkan temuan penelitian dapat disarankan bagi: (1) Bagi Kepala SMK Telkom Malang, hendaknya mengatasi faktor penghambat kerjasama sekolah dengan Cisco System agar pembelajaran Cisco Academy berjalan lancar. (2) Bagi Netacad Sucess Lead, Neatacad Instructur, dan Netacad Contact SMK Telkom Malang, hendaknya berperan sesuai fungsinya masing-masing. (3) Bagi peserta didik Cisco Academy, hendaknya memanfaatkan sertifikat Cisco untuk bersaing di dunia kerja. (4) Bagi dosen dan Ketua Jurusan Administrasi Pendidikan, hendaknya menjadikan kerjasama dalam bentuk kurikulum antara perusahaan dan sekolah sebagai salah satu materi dalam mata kuliah Manajemen Hubungan Masyarakat. (5) Bagi peneliti lain, hendaknya meneliti terkait hal belum berhasil diungkap terkait pengaruh Cisco Academy di SMK Telkom untuk meningkatkan penerimaan peserta didik di dunia kerja.

\section{DAFTAR RUJUKAN}

Alfianika, N. 2016. Metode Penelitian Pengajaran Bahasa Indonesia. Yogyakarta: Deepublish

Ali, M. 2009. Pendidikan untuk Pembangunan Nasional: Menuju Bangsa Indonesia yang Mandiri dan Berdaya Saing Tinggi. Jakarta: Grasindo.

Amsyah, Z. 2003. Manajemen Sistem Informasi. Jakarta: Gramedia.

Maisyaroh. 2004. Buku Ajar: Hubungan Masyarakat. Malang: FIP UM.

Sofana, I. 2012. Cisco CCNA dan Jaringan Komputer. Bandung: Informatika.

Sugiyono. 2009. Metode Penelitian Kuantitatif dan R \& D. Bandung: Alfabeta.

Suparmoko. 2007. Ekonomi. Jakarta: Yudhistira.

Sutopo, H., B. 2006. Penelitian Kualitatif: Dasar Teori dan Terapannya dalam Penelitian. Surakarta: Universitas Sebelas Maret.

Terry, G., R. 2009. Prinsip-Prinsip Manajemen. Jakarta: Bumi Aksara.

Torang, S. 2013. Organisasi dan Manajemen (Perilaku, Struktur, Budaya, dan Perubahan Organisasi). Bandung: Alfabeta.

Undang-undang Republik Indonesia Nomor 20 Tahun 2003 tentang Sistem Pendidikan Nasional. 2003. Bandung: Fokusmedia.

Wiyono, B. B. 2007. Metodologi Penelitian: Pendekatan Kuantitatif, Kualitatif, dan Action Researh (Burhanuddin, Ed). Malang: Universitas Negeri Malang.

Zazin, N. 2011. Gerakan Menata Mutu Pendidikan (Meita Sandra, Ed). Yogyakarta: Ar-Ruzz Media. 